\title{
Economic growth and poverty traps in sub-Saharan Africa: The role of education and TFP shocks is
}

\author{
Guido Cazzavillan ${ }^{\mathrm{a}}$, Michael Donadelli ${ }^{\mathrm{b}, *}$, Lauren Persha ${ }^{\mathrm{c}}$ \\ a Department of Economics, Ca' Foscari University of Venice, Venice, Italy \\ b Department of Economics and Finance, LUISS Guido Carli, Viale Romania 32, 00197 Rome, Italy \\ c Department of Geography, University of North Carolina at Chapel Hill, NC, United States
}

\section{A R T I C L E I N F O}

\section{Article history:}

Received 12 July 2012

Accepted 31 May 2013

Available online 19 June 2013

Keywords:

Average years of schooling

TFP Shocks

Capital accumulation

Poverty trap

\begin{abstract}
A B S T R A C T
This paper investigates the "education-total factor productivity trade-off" in explaining income per worker differences between sub-Saharan (unlucky) and G7 (lucky) economies. First, we examine the dynamics of average years of schooling (i.e. education), capital per worker, income per worker, and total factor productivity (TFP) across sub-Saharan and G7 countries. We confirm that physical capital and education levels partially explain income per worker differences between lucky and unlucky economies. Second, we undertake a novel examination of the impact of technology shocks on income per worker, with the goal of understanding the role of technology variation in causing cross-country income per worker differences, and as a potential contributor to overall slow growth in the sub-Saharan region. In a vector autoregressive (VAR) framework, we show that the impact of "ad hoc" TFP shocks on income per worker is larger in unlucky economies than in lucky ones. We observe that average TFP volatility in the "unlucky world" is eight times higher than in the "G7 world". We argue that the order of magnitude of the impact heavily depends on the level of the TFP volatility. Last, we suggest that the documented differences in the amount of physical capital and in the productivity of human capital between these two regions add conceptual support for the existence of poverty traps for sub-Saharan Africa.
\end{abstract}

(c) 2013 University of Venice. Published by Elsevier Ltd. All rights reserved.

\section{Introduction}

Income per worker varies substantially across countries around the world, and is attributed by much existing work to differences in human capital, physical capital, and total factor productivity (TFP) (see Caselli, 2005; Hall and Jones, 1999). Nevertheless, there is little consensus on the relative importance of each of these baskets of factors, and the role of human capital in promoting the economic development of a country is particularly widely debated. For example, Pritchett (1996) argues that data on the growth of years of schooling provide no support at all for the proposition that more rapid rates of growth in education capital produce greater income growth. He shows that the estimated impact of educational capital accumulation on a widely accepted growth accounting definition of TFP growth is large, negative, and statistically significant. That is, as the labor force becomes more educated, total factor productivity declines. He provides three possible explanations for this counter-intuitive result: (i) perhaps schooling has, on average, created no skills (i.e. no human capital);

\footnotetext{
We particularly thank Michele Battisti and Giovanna Vallanti for encouragement and detailed comments. The authors are also grateful to Massimo Franchi and Antonio Paradiso for their helpful comments and suggestions. Alessia Varani provided helpful research assistance. All errors are our own.

* Corresponding author. Tel.: +3906 85225972.

E-mail addresses: guido@unive.it (G. Cazzavillan), michael.donadelli@gmail.com (M. Donadelli), lpersha@email.unc.edu (L. Persha).
} 
(ii) perhaps the supply of educated people is higher than the demand (iii) perhaps schooling has increased worker intellectual skills, but an ineffective institutional environment provides little opportunity for workers to use these skills in value-added activities (i.e. human capital has been badly invested). In showing that education is not a sufficient condition for growth, Pritchett (1996) does not seek to advance the idea that education is powerless, but instead provides empirical support for a of focus on complementary reforms in non-educational sectors that can facilitate educational investments to pay off.

This emphasis also reflects recent empirical findings supporting the weak explanatory power for education alone as a driver of cross-country income differences. Increasingly, institutions are also conceptualized to play an important role in mediating links between various forms of human capital (such as education) and country growth. North's (1990) broad articulation of institutions as the formal and informal "rules of the game" in a society serves to illustrate their importance. He argues that by encompassing the structural fabric which shapes interactions between people, institutions incentivize societies to behave in certain ways, and as such serve as the underlying determinants of economic performance (North, 1994). Relatedly, Hall and Jones (1999) and Caselli (2005) argue that differences in income per worker might have more to do with differences in social infrastructure across countries, while Shleifer and Vishny (1993), Mauro (1995), and Ehrlich and Lui (1999) argue that corruption hampers economic growth. Hall and Jones (1999) and Acemoglu et al. (2003) both demonstrate the importance of an institutional environment in explaining economic growth by showing that countries with different levels of institutional quality have different economic growth rates.

Other researchers also highlight the complicating role that globalization brings to bear on these dynamics, while the extent to which education comes into play continues to be debated. Mazur (2000) argues that globalization has dramatically increased cross-country income differences. Kremer and Maskin (2003) argue that globalization has marginalized the poor in developing countries and left behind the poorest countries. Clinton (2000), during a session on the Indian parliament, argues that the poor must invest in education to take advantage of globalization. But, related empirical evidence suggest that although the average years of schooling both in primary and secondary school sharply increased in several poor economies over the last 20 years, income inequalities are still high.

Other work focuses more explicitly on technology as the key force behind economic growth. Hall and Jones (1999) show that differences in physical capital and educational attainment can only partially explain the variation in income per worker. They find a large amount of variation in the level of the TFP (i.e. Solow residual/technological progress) across countries, and they also argue that differences in capital accumulation, productivity, and therefore income per worker might be driven by differences in institutions and government policies, which they call social infrastructure. Caselli (2005) also argues that the observed differences in the factors employed in production do not totally explain most of the cross-country variation in income, but claims that human capital measures rather than social infrastructure should account for differences not only in the quality of schooling, but also in the health status of the population, which has accumulated repercussions for worker productivity overall.

In the context of the enduring sub-Saharan growth puzzle, a large part of the literature has focused on the role of institutions and governance as explanatory variables for low economic growth rates, while few works have been devoted to explicitly studying the dynamics of TFP and its impact on cross-country income per worker. However, technology differences are clearly also a plausible driver. For instance, Sachs (2001) presents evidence that production technology in the tropics has lagged behind temperate zone technology in the two critical areas of agriculture and health, and this in turn opened a substantial income gap between climate zones.

Here, we use a development accounting framework to first examine TFP and human capital differences between lucky (G7) and unlucky (sub-Saharan) economies. Second, we analyze the impact of TFP uncertainty shocks on per capita income. Following the growth accounting setup of Hall and Jones (1999) and Caselli (2005), we observe that differences in physical capital and education between sub-Saharan and G7 economies do not fully explain the huge gap in income per worker. Not surprisingly, we find evidence that the TFP plays a crucial role in understanding the existence of a crosscountry income puzzle. Unlucky economies' average TFP accounts only for $27 \%$ of the US TFP. Our empirical findings in the first part of our analyses confirm existing results on the relationships between physical capital, education levels, and income (see Hall and Jones, 1999 and Caselli, 2005). To better understand the role of TFP in this complex puzzle, we undertake in the second part of the paper a novel examination of the impact of rare events (i.e. TFP uncertainty shocks)defined as those with TFP growth rate more than 1.43 standard deviations above (below) the Hodrick-Prescott detrended mean of the TFP growth rate series- on income per worker, with the goal of understanding the key role played by technology variation in causing cross-country income differences, and as a potential contributor to overall slow growth in the sub-Saharan region.

The paper is organized as follows. Section 2 describes the data. Section 3, at the country level, in a growth accounting framework, determines the income per worker, education and technological progress, and examines the impact of TFP uncertainty shocks on income per worker. Section 4 discusses the link between our empirical findings, conventional theoretical economic results and poverty in sub-Saharan countries. Section 5 concludes.

\section{Data description and preliminary analysis}

In 2010, the thirty-two sub-Saharan countries on which we focus on had a combined population of 516 million and an average annual per capita income of $\$ 3270.00$ (i.e. $\$ 9$ per day). For comparison purposes, we use the G7 economies as 
Table 2.1

Unlucky (sub-Saharan Africa) and Lucky (G7) economies.

\begin{tabular}{llll}
\hline Unlucky economies & & & \\
\hline Benin & Gabon & Mauritania & South Africa \\
Botswana & Gambia & Mauritius & Candan \\
Burundi & Ghana & Mozambique & Swaziland \\
Cameroon & Kenya & Namibia & Tanzania \\
Central African Rep. & Lesotho & Niger & Togo \\
Congo, Rep. The & Liberia & Rwanda & Uganda \\
Cote d'Ivoire & Malawi & Senegal & Zambia \\
Dem. Rep. of Congo & Mali & Sierra Leone & Zimbabwe \\
\hline
\end{tabular}

benchmark. The complete list of countries is presented in Table 2.1. In 2010, the G7 had a population of 735 million an average annual per capita income of $\$ 35,278.00$ (i.e. $\$ 98$ per day). Average savings to GDP ratios over the sample 1980-2011 are $14.87 \%$ and $20.69 \%$ for the sub-Saharan and G7 countries, respectively. Data are from the International Monetary Fund (IMF) and include all countries listed in Table 2.1.

The relevant macro-variables (i.e. time series) in this paper are obtained using the empirical procedure developed by Hall and Jones (1999), and Caselli (2005). We assume that output $Y$ is produced according to the following production function

$$
Y=A K^{\alpha}(L h)^{1-\alpha}
$$

where $K$ is the aggregate capital stock and $L h$ is the quality adjusted workforce, namely the number of workers $L$ multiplied by the average human capital $h$ and $A$ corresponds to the TFP. Throughout the paper we use the terms total factor productivity, Solow's residual, or technological progress interchangeably. In per worker terms the production function can be written as follows:

$$
Y=A k^{\alpha} h^{1-\alpha}
$$

where $k$ is the capital labor ratio.

As investigated by Hall and Jones (1999), and by Caselli (2005), we are initially interested in studying how much of the cross-country income gap can be explained by each specific production factor (i.e. $A, h$ and $k$ ). To address the issue, we use the following set of info: (i) output/income per worker (i.e. $y$ ); (ii) capital labor ratio (i.e. $k$ ); (iii) total average years of schooling (i.e. $h$ ); (iv) value for the capital share $\alpha$.

Our dataset combines variables from two sources. The first is version 7.0 of the PENN WORLD TABLES. ${ }^{2}$ From PENN TABLES, we extract output, capital and the number of workers. The second is the Barro-Lee educational attainment dataset. The latter is used to find data on the average years of schooling. ${ }^{3}$ Data run from 1950 (or later) to $2009 .{ }^{4}$ The variable $y$ is measured from PWT63 as real GDP per worker in international dollars (i.e. in PPP, this variable is called rgdpwok in the original data set).

The capital stock, $K$, is computed using the standard perpetual inventory equation

$$
K_{t}=I_{t}+(1-\delta) K_{t-1}
$$

where $I_{t}$ is investment and $\delta$ is the depreciation rate (assumed to be equal to 0.06). We compute the investment series as real aggregate investment in PPP. In practice, $I=r g d p l \times p o p \times k i$, where $r g d p l$, pop and $k i$ represent the real income per capita, the population (in thousands) and the investment share of PPP converted GDP per capita at 2005 constant prices (i.e. investment share in total income), respectively.

We estimate the initial value of capital stock $K_{0}$ as $I_{0} /(\delta+g)$ where $I_{0}$ is the value of the investment series in the first year it is available (i.e. in our dataset the initial investment value ranges from 1950 to 1970), and $g$ represents the average geometric growth rate for the investment series computed over the first twenty years of available data. To compute $k$, we divide $K$ by the number of workers. The latter is obtained as $r g d p c h \cdot p o p / r g d p w o k$, where $r g d p c h$ is real GDP per capita computed with the chain method.

\footnotetext{
${ }^{1}$ Savings to GDP ratio data for Liberia and Zimbabwe are not available. Per capita GDP per worker are based on purchasing-power-parity (PPP) in current international dollar.

2 The PENN WORLD TABLES time series are publicly available online from https://pwt.sas.upenn.edu.

3 The Barro-Lee educational attainment dataset is publicly available online from http://www.barrolee.com.

4 PENN TABLE starting dates (in parentheses): Benin (1959), Botswana (1960), Burundi (1960), Cameroon (1960), Central Afr. Rep. (1960), Congo (1960), Cote d'Ivoire (1960), Dem. Rep. of Congo (1950), Gabon (1960), Gambia (1960), Ghana (1955), Kenya (1950), Lesotho (1960), Liberia (1970), Malawi (1954), Mali (1960), Mauritania (1960), Mauritius (1950), Mozambique (1960), Namibia (1960), Niger (1960), Rwanda (1960), Senegal (1960), Sierra Leone (1961), South Africa (1950), Sudan (1970), Swaizland (1970), Tanzania (1960), Togo (1960), Uganda (1950), Zambia (1955), Zimbabwe (1954), Canada (1950), France (1950), Germany (1970), Italy (1950), Japan (1950), UK (1950) and USA (1950).
} 
To construct the human capital series, $h$, we use the average years of schooling in the population over 25 years old from the Barro-Lee educational attainment dataset. As in Hall and Jones (1999), the human capital, $h$, is computed as follows:

$$
h=e^{\theta(s)}
$$

where $s$, which is observed in the data every five years, is the average years of schooling, and $\theta(s)$ is piecewise linear function. ${ }^{5,6}$ The last parameter to be determined is $\alpha$. As suggested by literature, we assume capital share to be $1 / 3$. The TFP (i.e. $A$ ) is obtained as residual of Eq. (2.2). Formally,

$$
A=\frac{y}{k^{\alpha} h^{1-\alpha}} \text {. }
$$

In this paper, we also construct country-by-country ad hoc TFP shock series, which we then use to examine the relationship between changes in technology and economic growth. To measure shocks, we use an indicator series that takes a value of 1 , once an "extraordinary event", either positive or negative, occurs, and a value of 0 , otherwise. An extraordinary event is defined as that with TFP growth rate more (less) than 1.43 standard-deviations above (below) the Hodrick-Prescott detrended mean of the TFP growth rate series (see Bloom, 2009; Cazzavillan and Donadelli, 2013). Formally, a 1 is assigned if the rate of growth of $A$ is below or above the following thresholds

$$
\text { TFP Shock } \text { S }_{t}^{h p} \pm 1.43 \sigma_{A}
$$

where $\mu_{t}^{h p}$ represents the mean of the Hodrick-Prescott filtered TFP growth rate series and $\sigma_{A}$ is the standard deviation of the TFP growth rate.

To study the contribution of each production input to income, we employ the log version of Eq. (2.2). Formally,

$$
\log (y)=\log (A)+\alpha \log (k)+(1-\alpha) \log (h) .
$$

Results are reported in Table 2.2, and suggest that income is mostly determined by physical capital (i.e. $\alpha \log (k))$ and technological factors (i.e. $\log (A)$ ), while educational attainment plays a less important role. Over the 32 sub-Saharan countries in our dataset, the quantity $(1-\alpha) \log (h) / \log (y)$ is on average equal to $3.18 \%$. The average contribution of capital per worker and TFP to income is equal to $55.28 \%$ and $41.54 \%$, respectively. Similar results are obtained for the G7 economies. Human capital, here captured by the average years of schooling, appears to contribute only marginally to the income per worker, and is perhaps suggestive of the existence of institutional or related barriers that prevent countries with more highly educated workers in subSaharan Africa from utilizing those skills in ways that translate into higher growth. Alternatively, it is also possible that the benefits of increased educational skills operate under a threshold effect, with the generally low levels of education across all countries on the continent yet to reach that threshold (even for countries with higher educational attainment than their peers). The preliminary results of Table 2.2 pave the way to study separately the contribution of the income per worker, human capital and TFP in solving the cross-country income differences puzzle, as well as to examine the impact of variation (i.e. uncertainty shocks) in the level of technology on the income per worker.

\section{Cross-country income differences: An empirical review}

\subsection{Income, education and TFP: Some stylized facts}

Hall and Jones (1999) find a large amount of variation in the level of the Solow residual (TFP) across countries. Their main hypothesis is that differences in capital accumulation, productivity, and therefore income per worker are fundamentally related to differences in social infrastructure, that is, institutions, across countries. Caselli (2005), using the benchmark Hall and Jones' (1999) production function, argues that only a small fraction of cross-country income variance can be attributed to differences in (physical and human) capital. In particular, he finds that the fraction of the variance of income explained by such observed endowments is equal to $0.39 .^{7}$ This implies that a large portion of the variance is explained by TFP (Solow's residual). This empirical consistency supports our curiosity to investigate the impact of TFP shocks on per capita income, in order to better understand the role of technology changes in promoting economic growth and development in sub-Saharan Africa.

In Table 3.1, we report the summary statistics of the population, income per worker, education level and physical capital per worker. All time series are obtained following the procedure described in Section 2. In addition, we report the average values of the growth rate of the population and capital per worker, as well as the variance of the TFP growth rate. Statistics are computed on a country-by-country basis. Columns three, four and six of Table 3.1 confirm Hall and Jones' (1999) main results, in that they show that the average growth rate of income per worker is lower across unlucky economies than across lucky economies (i.e. $1.060 \%$ vs $2.280 \%$ ). Results also show that the sub-Saharan average capital stock is one-tenth of the

\footnotetext{
${ }^{5}$ The structure of the piecewise linear function $\theta(s): \theta(s)=0.134 \cdot s i f s \leq 4, \theta(s)=0.134 \times 4+0.101 \times(s-4)$ if $4<s \leq 8$ and $\theta(s)=0.134 \times 4+0.101 \times 4+$ $0.068 \times(s-8)$ if $s>8$.

${ }^{6}$ Caselli (2005) justifies the low frequency in the average years of schooling dataset as follows: "since $s$ moves slowly over time, a quinquennial observation can plausibly be employed for nearby dates as well".

${ }^{7}$ Formally, Caselli (2005) uses the following measure of success: $\operatorname{succes}{ }_{1}=\operatorname{var}\left[\log \left(y_{h k}\right)\right] / \operatorname{var}[\log (y)]$ where $y_{h k}=k^{\alpha} h^{1-\alpha}$, and refers to $y_{h k}$ as the factoronly model.
} 
Table 2.2

The elements of this table represent the average contribution of each input to total income per worker (numbers are expressed in percentage points). According to data availability, mean values might be computed using a different number of years. Series are annually and run from 1950 to 2009 . Source: PENN WORLD Tables, Barro-Lee dataset.

\begin{tabular}{|c|c|c|c|}
\hline Country & $\frac{\alpha \log (k)}{\log (y)}$ & $\frac{(1-\alpha) \log (h)}{\log (y)}$ & $\frac{\log (A)}{\log (y)}$ \\
\hline \multicolumn{4}{|l|}{ Sub-Saharan Africa } \\
\hline Benin & 56.81 & 1.94 & 41.25 \\
\hline Botswana & 53.41 & 4.17 & 42.42 \\
\hline Burundi & 56.43 & 2.11 & 41.46 \\
\hline Cameroon & 53.32 & 3.43 & 43.26 \\
\hline Central African Republic & 56.01 & 2.30 & 41.69 \\
\hline Congo, Republic The & 55.81 & 4.01 & 40.19 \\
\hline Cote d'Ivoire & 52.25 & 2.49 & 45.27 \\
\hline Democratic Republic of Congo & 56.92 & 2.41 & 40.67 \\
\hline Gabon & 52.49 & 3.31 & 44.20 \\
\hline Gambia & 53.11 & 1.67 & 45.23 \\
\hline Ghana & 60.81 & 4.73 & 34.46 \\
\hline Kenya & 55.22 & 3.96 & 40.82 \\
\hline Lesotho & 55.11 & 4.92 & 39.97 \\
\hline Liberia & 60.72 & 3.19 & 36.09 \\
\hline Malawi & 61.79 & 2.80 & 35.41 \\
\hline Mali & 55.66 & 0.81 & 43.53 \\
\hline Mauritania & 57.20 & 2.70 & 40.09 \\
\hline Mauritius & 54.56 & 4.60 & 40.85 \\
\hline Mozambique & 56.04 & 1.35 & 42.61 \\
\hline Namibia & 52.92 & 4.39 & 42.68 \\
\hline Niger & 55.86 & 0.98 & 43.16 \\
\hline Rwanda & 53.18 & 2.31 & 44.52 \\
\hline Senegal & 53.50 & 3.38 & 43.12 \\
\hline Sierra Leone & 53.66 & 2.07 & 44.27 \\
\hline South Africa & 52.07 & 4.79 & 43.14 \\
\hline Sudan & 49.53 & 1.97 & 48.50 \\
\hline Swaziland & 53.29 & 4.87 & 41.84 \\
\hline Tanzania & 56.69 & 4.05 & 39.27 \\
\hline Togo & 56.44 & 3.21 & 40.35 \\
\hline Uganda & 54.61 & 2.92 & 42.47 \\
\hline Zambia & 54.73 & 4.29 & 40.98 \\
\hline Zimbabwe & 58.94 & 5.61 & 35.46 \\
\hline \multicolumn{4}{|l|}{ Advanced economies } \\
\hline Canada & 49.47 & 6.46 & 44.07 \\
\hline France & 50.02 & 4.76 & 45.22 \\
\hline Germany & 50.80 & 5.33 & 43.87 \\
\hline Italy & 50.58 & 4.91 & 44.51 \\
\hline Japan & 50.61 & 6.25 & 43.14 \\
\hline United Kingdom & 49.01 & 5.57 & 45.43 \\
\hline United States & 49.45 & 7.03 & 43.52 \\
\hline Mean (32 sub-Saharan) & 55.28 & 3.18 & 41.54 \\
\hline Mean (7 Developed) & 49.99 & 5.76 & 44.25 \\
\hline
\end{tabular}

stock of capital averaged across the G7 economies. The average capital per worker and the average TFP growth rate in the unlucky world are $2.339 \%$ and $-0.053 \%$, respectively. In the lucky world, we get the following values: $3.381 \%$ and $0.686 \%$, respectively. In contrast to the standard neoclassical growth theory, our findings suggest that economies with low level of capital tend to grow at a lower rate and accumulate a low amount of capital through time.

We also observe that there is substantial heterogeneity in these summary statistics within the sub-Saharan zone. For example, the income per worker ranges from $\$ 728.57$ (Burundi) to $\$ 23,066.90$ (Gabon), and the capital per worker ranges from $\$ 75,800.33$ (Burundi) to $\$ 7436,666.28$ (Gabon). However, the gap with the G7 economies is still significantly high, and only one sub-Saharan economy in our dataset (Gabon) seems to show income and capital outcomes on par with those of G7 economies. The income per worker interval goes from a min of $\$ 38,014.08$ (Japan) to a max of $\$ 56,281.49$ (USA); and goes from a min of $\$ 6932,284.44$ (UK) to a max of $\$ 15,704,562.07$ (Germany) for the capital per worker. ${ }^{8}$ Average years of schooling min-max intervals are: [0.02 (Mozambique)-5.68 (South Africa)] and [6.36 (France)-11.14 (U.S.)].

We summarize our empirical findings as follows: (i) the absolute convergence theory, suggested by the neoclassical growth theory, does not apply; ${ }^{9}$ (ii) the rate of growth of the technological progress across unlucky economies is on average

\footnotetext{
${ }^{8}$ The minimum and maximum values are country specific sample averages. Data run from 1950 or later to 2009.

${ }^{9}$ A detailed discussion is provided in Section 4.
} 
Table 3.1

The elements of this table represent the mean values of the rate of growth of the population $(p o p)$, output per worker $\left(\bar{y}_{t}\right)$, capital per worker $\left(\bar{k}_{t(\%)}\right)$, the human capital $\left(\bar{h}_{t}\right)$ and Solow's residual $(\bar{A})$. The 6th column represents the mean of the stock of capital per worker (measured in millions of US dollars). The last column displays the variance of the TFP growth rate $\left(\sigma_{A}^{2}\right)$. Numbers are all expressed in percentage points. Data run from 1950 (or later) to 2009. Sources: PENN WORLD Tables, Barro-Lee dataset.

\begin{tabular}{|c|c|c|c|c|c|c|c|}
\hline Country & Pop. & $\mathrm{y}$ & $k$ & $h$ & k (per capita) & $A$ & $\operatorname{Var}(\mathrm{A})$ \\
\hline \multicolumn{8}{|l|}{ Sub-Saharan Africa } \\
\hline Benin & 2.854 & 1.150 & 1.101 & 1.579 & $580,529.9$ & 0.225 & 0.277 \\
\hline Botswana & 2.636 & 6.508 & 11.208 & 4.290 & $2,722,750.3$ & 1.697 & 0.752 \\
\hline Burundi & 2.399 & 0.895 & 2.537 & 1.400 & $75,800.3$ & -0.331 & 0.580 \\
\hline Cameroon & 2.319 & 1.143 & 3.780 & 2.963 & $785,174.8$ & -0.869 & 0.278 \\
\hline Central African Republic & 2.273 & -0.764 & -2.562 & 1.680 & $296,073.1$ & -0.439 & 0.216 \\
\hline Congo, Republic The & 2.716 & 2.213 & -0.437 & 3.513 & $1,125,737.8$ & 1.605 & 0.636 \\
\hline Cote d'Ivoire & 3.410 & 0.700 & 1.170 & 2.084 & $431,322.5$ & -0.252 & 0.237 \\
\hline Democratic Republic of Congo & 2.797 & -1.179 & -0.886 & 1.924 & $296,502.5$ & -1.334 & 1.536 \\
\hline Gabon & 2.227 & 2.298 & 2.344 & 3.509 & $7,436,666.3$ & 0.419 & 0.683 \\
\hline Gambia & 3.173 & 1.256 & 4.435 & 1.276 & $194,579.3$ & -0.664 & 0.455 \\
\hline Ghana & 2.591 & 2.008 & -1.164 & 4.052 & $1,087,550.4$ & 1.537 & 1.326 \\
\hline Kenya & 3.190 & 0.379 & -0.004 & 3.732 & $430,677.6$ & -0.375 & 0.244 \\
\hline Lesotho & 1.657 & 2.784 & 12.666 & 4.058 & $494,800.0$ & -1.418 & 0.538 \\
\hline Liberia & 2.585 & -1.470 & -4.900 & 1.995 & $993,403.5$ & -0.279 & 5.415 \\
\hline Malawi & 2.886 & 2.477 & 3.711 & 2.207 & $648,237.1$ & 0.654 & 0.971 \\
\hline Mali & 2.220 & -3.418 & 3.912 & 0.641 & $395,543.5$ & 0.097 & 0.379 \\
\hline Mauritania & 1.945 & 2.407 & 1.770 & 2.311 & $1,021,951.2$ & 1.383 & 0.873 \\
\hline Mauritius & 1.681 & 1.727 & 1.176 & 5.138 & $3,594,133.1$ & 0.720 & 0.338 \\
\hline Mozambique & 2.160 & 1.837 & 3.414 & 0.022 & $99,453.8$ & 0.627 & 0.231 \\
\hline Namibia & 2.604 & 1.104 & 2.028 & 4.569 & $3,497,271.6$ & -0.063 & 0.253 \\
\hline Niger & 2.677 & -0.083 & 1.930 & 0.759 & $354,120.5$ & -0.919 & 0.418 \\
\hline Rwanda & 2.642 & 1.304 & 3.419 & 1.677 & $144,542.2$ & -0.345 & 1.666 \\
\hline Senegal & 2.601 & 0.242 & 2.710 & 2.858 & $406,108.6$ & -1.139 & 0.202 \\
\hline Sierra Leone & 1.558 & 1.204 & 4.485 & 1.559 & $247,637.8$ & -0.611 & 0.598 \\
\hline South Africa & 2.201 & 1.149 & 1.577 & 5.684 & $4,255,861.4$ & 0.188 & 0.109 \\
\hline Sudan & 2.875 & 1.545 & 3.368 & 1.447 & $304,383.5$ & -0.010 & 0.924 \\
\hline Swaziland & 2.705 & 2.779 & 2.820 & 4.081 & $1,719,355.8$ & 0.957 & 0.675 \\
\hline Tanzania & 2.825 & 0.096 & 4.103 & 3.107 & $232,829.8$ & 0.096 & 0.181 \\
\hline Togo & 2.928 & -0.055 & 1.949 & 2.533 & $621,269.6$ & -1.479 & 0.404 \\
\hline Uganda & 3.044 & 1.370 & 2.413 & 2.519 & $171,091.1$ & -0.005 & 0.249 \\
\hline Zambia & 2.806 & 0.826 & 0.035 & 4.007 & $844,676.3$ & 0.136 & 0.790 \\
\hline Zimbabwe & 2.384 & -0.512 & 0.743 & 4.353 & $127,199.8$ & -1.501 & 0.886 \\
\hline \multicolumn{8}{|l|}{ Advanced economies } \\
\hline Canada & 1.490 & 1.401 & 2.118 & 9.568 & $9,362,137.2$ & 0.333 & 0.053 \\
\hline France & 0.707 & 2.588 & 3.671 & 6.361 & $9,739,378.0$ & 0.810 & 0.066 \\
\hline Germany & 0.306 & 1.359 & 0.669 & 6.769 & $15,704,562.1$ & 0.201 & 0.100 \\
\hline Italy & 0.424 & 3.240 & 4.400 & 6.535 & $11,348,080.5$ & 1.275 & 0.057 \\
\hline Japan & 0.709 & 3.850 & 6.960 & 9.064 & $10,997,926.0$ & 1.287 & 0.308 \\
\hline United Kingdom & 0.361 & 1.871 & 3.778 & 7.604 & $6,932,284.4$ & 0.283 & 0.039 \\
\hline United States & 1.196 & 1.649 & 2.068 & 11.139 & $11,241,901.5$ & 0.614 & 0.063 \\
\hline Mean(32 sub-Saharan) & 2.549 & 1.060 & 2.339 & 2.735 & $1,113,663.6$ & -0.053 & 0.729 \\
\hline Sd (32 sub-Saharan) & 0.444 & 1.673 & 3.279 & 1.397 & ... & 0.895 & 0.941 \\
\hline Mean (7 Advanced) & 0.742 & 2.280 & 3.381 & 8.149 & $10,760,895.7$ & 0.686 & 0.098 \\
\hline Sd (7 Advanced) & 0.448 & 0.972 & 2.032 & 1.816 & $\ldots$ & 0.457 & 0.094 \\
\hline
\end{tabular}

negative (i.e. $-0.053 \%) ;{ }^{10}$ (iii) the average rate of growth of capital per worker is negative in 6 out of 32 unlucky economies (i.e. lack in capital accumulation); (iv) on average, the stock of capital per worker across lucky economies is ten times higher than across unlucky economies.

Our numbers also support past empirical findings stating that differences in physical capital and in educational attainment explain only a small fraction of the differences in income per worker across countries (see Caselli, 2005; Hall and Jones, 1999 among others). In Table 3.2, we report country-by-country empirical counterparts of Eq. (2.2). In particular, we weight the average production input of each sub-Saharan and G7 economy $i$ over the average production component of the US. Formally,

$$
y_{i}^{w}=\frac{\bar{y}_{i}}{\bar{y}_{\mathrm{US}}} ; \quad k_{i}^{w}=\frac{\bar{k}_{i}^{\alpha}}{\bar{k}_{\mathrm{US}}^{\alpha}} ; \quad h_{i}^{w}=\frac{\bar{h}_{i}^{1-\alpha}}{\bar{h}_{\mathrm{US}}^{1-\alpha}} ; \quad A_{i}^{w}=\frac{\bar{A}_{i}}{\bar{A}_{\mathrm{US}}} .
$$

\footnotetext{
${ }^{10}$ Negative average TFP growth rates are found in the following sub-Saharan countries: Burundi, Cameroon, Central African Republic, Cote d'Ivoire, Dem. Rep. of Congo, Gambia, Kenya, Lesotho, Liberia, Niger, Namibia, Rwanda, Senegal, Sierra Leone, Sudan, Togo, Uganda, Zimbabwe.
} 
Table 3.2

The elements of this table are the empirical counterparts to the components of Eq. (2.2), all measured as ratios to the U. S. values. The first column is the product of the other three columns. Data run from 1950 or later to 2009.

Sources: PENN WORLD Tables, Barro-Lee dataset.

\begin{tabular}{|c|c|c|c|c|}
\hline \multirow[t]{2}{*}{ Country } & \multirow[b]{2}{*}{$y$} & \multicolumn{3}{|c|}{ Productivity factors: contribution } \\
\hline & & $k^{\alpha}$ & $h^{1-\alpha}$ & $A$ \\
\hline \multicolumn{5}{|l|}{ Advanced economies } \\
\hline United States & 1.000 & 1.000 & 1.000 & 1.000 \\
\hline Canada & 0.874 & 0.942 & 0.931 & 0.996 \\
\hline France & 0.793 & 0.934 & 0.776 & 1.093 \\
\hline Germany & 0.948 & 1.132 & 0.836 & 1.002 \\
\hline Italy & 0.791 & 0.974 & 0.785 & 1.035 \\
\hline Japan & 0.675 & 0.918 & 0.892 & 0.825 \\
\hline United Kingdom & 0.760 & 0.835 & 0.839 & 1.084 \\
\hline \multicolumn{5}{|l|}{ Sub-Saharan economies } \\
\hline Benin & 0.043 & 0.376 & 0.541 & 0.213 \\
\hline Botswana & 0.175 & 0.568 & 0.697 & 0.441 \\
\hline Burundi & 0.013 & 0.187 & 0.533 & 0.130 \\
\hline Cameroon & 0.081 & 0.405 & 0.624 & 0.320 \\
\hline Central African Republic & 0.031 & 0.297 & 0.551 & 0.191 \\
\hline Congo, Republic The & 0.079 & 0.470 & 0.656 & 0.255 \\
\hline Cote d'Ivoire & 0.068 & 0.338 & 0.571 & 0.354 \\
\hline Democratic Republic of Congo & 0.034 & 0.300 & 0.551 & 0.204 \\
\hline Gabon & 0.410 & 0.869 & 0.656 & 0.719 \\
\hline Gambia & 0.035 & 0.255 & 0.527 & 0.257 \\
\hline Ghana & 0.036 & 0.460 & 0.673 & 0.116 \\
\hline Kenya & 0.045 & 0.341 & 0.640 & 0.205 \\
\hline Lesotho & 0.035 & 0.319 & 0.674 & 0.162 \\
\hline Liberia & 0.047 & 0.438 & 0.586 & 0.182 \\
\hline Malawi & 0.023 & 0.378 & 0.569 & 0.109 \\
\hline Mali & 0.038 & 0.323 & 0.493 & 0.241 \\
\hline Mauritania & 0.057 & 0.452 & 0.577 & 0.218 \\
\hline Mauritius & 0.189 & 0.687 & 0.713 & 0.386 \\
\hline Mozambique & 0.016 & 0.206 & 0.507 & 0.154 \\
\hline Namibia & 0.231 & 0.681 & 0.704 & 0.482 \\
\hline Niger & 0.037 & 0.318 & 0.499 & 0.232 \\
\hline Rwanda & 0.029 & 0.232 & 0.551 & 0.225 \\
\hline Senegal & 0.054 & 0.331 & 0.609 & 0.267 \\
\hline Sierra Leone & 0.039 & 0.279 & 0.544 & 0.254 \\
\hline South Africa & 0.309 & 0.727 & 0.742 & 0.572 \\
\hline Sudan & 0.085 & 0.300 & 0.549 & 0.514 \\
\hline Swaziland & 0.141 & 0.536 & 0.722 & 0.365 \\
\hline Tanzania & 0.024 & 0.273 & 0.624 & 0.143 \\
\hline Togo & 0.046 & 0.378 & 0.600 & 0.202 \\
\hline Uganda & 0.028 & 0.249 & 0.578 & 0.193 \\
\hline Zambia & 0.074 & 0.422 & 0.663 & 0.264 \\
\hline Zimbabwe & 0.014 & 0.227 & 0.677 & 0.093 \\
\hline Mean (6 Developed) & 0.807 & 0.956 & 0.843 & 1.006 \\
\hline Sd (6 Developed) & 0.086 & 0.090 & 0.055 & 0.089 \\
\hline Mean (32 Sub-Saharan) & 0.080 & 0.394 & 0.606 & 0.271 \\
\hline Sd (32 Sub-Saharan) & 0.089 & 0.161 & 0.070 & 0.142 \\
\hline
\end{tabular}

All bar variables in Eq. (3.1.1) denote average values. Data suggests that, under this benchmark production function, the TFP plays a crucial role in explaining why sub-Saharan countries are not able to emerge from relative stagnation into more productive economies. Especially, our findings show that the differences in the level of technology between unlucky and lucky economies are huge, an in particular, are higher than human and physical capital differences. In fact, the average sub-Saharan TFP is less than one-third of the U.S. TFP. In contrast, education and capital per worker across sub-Saharan economies seem to be closer to US education and capital per worker values (i.e. 60\% and 40\%, respectively). Results, reported in the second and last column of Table 3.2, are summarized in the relations defined in Eq. (3.1.2).

$$
\frac{\bar{k}_{i}^{\alpha}}{\overline{\bar{k}}_{\mathrm{US}}^{\alpha}}<\frac{\bar{h}_{i}^{1-\alpha}}{\bar{h}_{\mathrm{US}}^{1-\alpha}} \cup \frac{\bar{A}_{i}}{\overline{\bar{A}}_{\mathrm{US}}}<\frac{\bar{h}_{i}^{1-\alpha}}{\bar{h}_{\mathrm{US}}^{1-\alpha}}
$$

Hall and Jones (1999) argue that one possible interpretation of this result is that other differences in labor skills are also important, such as the quality of human capital. These inputs might be considered directly in the production function. They ultimately claim that a theory of productivity differences is needed. 
For example, Parente and Prescott (1994) propose a theory of economic development in which technology adoption and barriers to such adoptions are the focus. Based on the fact that the size of these barriers differs across countries and time, they construct a theory where it is shown that the larger these barriers to technology uptake, the greater the investment a firm must make to adopt a more advanced technology.

These results suggest that additional insights can be gained by conducting an analysis on cross-country income differences focusing only on the TFP and capital per worker gaps rather than on the education gap. Since cross-country differences in the level of technology appear to be key, the rest of the paper is devoted to study the impact of variation in the TFP level on income per worker.

\subsection{TFP shocks: Do they matter?}

As discussed in Section 3.1, the TFP component emerges as a more important factor than education (i.e. average years of schooling) in understanding cross-country income per worker differences, as well as in exacerbating output instability. In this work, we abstract from the political or social instability issues to focus instead, via time series analysis, on the magnitude of the impact of TFP shocks on income per worker. This is because we posit that the TFP represents the most important source of the presence of huge income differences between the sub-Saharan Africa and the advance economies world. We stress that our empirical setup allows us to conduct the analysis on a country-bycountry basis. The TFP shock indicator (i.e. TFP uncertainty shock) series is derived as discussed in Section 2 . For each country we get two series: one collects positive shocks and one collects negative shocks. Shock series appear as $0 / 1$ indicator variables. Our ad hoc shocks (i.e. extraordinary events) are reported, on yearly basis, in Table A.1. Positive or negative signs - in parentheses - confirm the presence of extreme movements in the TFP growth rate series. In the spirit of Bloom (2009) and Cazzavillan and Donadelli(2013), we assume that to each extreme event corresponds a financial, political or social shock. The effects of TFP shocks on income per worker are studied via a vector autoregressive (VAR) analysis. A standard $\operatorname{VAR}(p, k)$ takes the following form

$$
X_{t}=A_{1} X_{t-1}+\cdots \cdots+A_{k} X_{t-k}+W_{t}
$$

where $W_{t} \sim W N(0, \Omega)$. In (3.2.1) $X_{t}$ is a $(p \cdot 1)$ vector of variables and $k$ represents the numbers of lags. To evaluate the impact of TFP shocks on income per worker, we estimate, at the country level, a set of bivariate VARs. The full set of variables used in our VAR estimations includes the income per worker growth rate $\left(\Delta y_{t}\right)$ and TFP shock indicator series $\left(T F P^{\text {Shock }}\right)$. In this framework, the VAR specification in Eq. (3.2.1) can be written as

$$
\underbrace{\left[\begin{array}{c}
T F P_{t}^{\text {Shock }} \\
\Delta y_{t}
\end{array}\right]}_{X_{t}}=\underbrace{\left[\begin{array}{ll}
a_{11} & a_{12} \\
a_{21} & a_{22}
\end{array}\right]}_{A_{1}} \underbrace{\left[\begin{array}{c}
T F P_{t-1}^{S h o c k} \\
\Delta y_{t-1}
\end{array}\right]}_{X_{t-1}}+\underbrace{\left[\begin{array}{c}
w_{T F P t} \\
w_{\Delta y t}
\end{array}\right]}_{W_{t}},
$$

where $A_{1}$ is the matrix of coefficients and $k$ is assumed to be 1. Our VARs' estimates are computed using robust standard errors (i.e. HAC procedure). The optimal number of lags, $k$, is chosen according to the BIC lag selection criteria. To compute impulse responses, the $1 / 0$ TFP shock series is ordered last in a Cholesky decomposition. This specification implies that the second shock does not affect the first variable contemporaneously, but both shock have a contemporaneous effect on the second variable.

The main result here is that the impact of the ad hoc TFP shock series on income per worker is larger in the unlucky world rather than in the lucky one. Impulse response functions (IRFs), computed via the estimation of Eq. (3.2.1), are reported, on a country-by-country basis, in Figs. A.4-A.7. For space reasons, we report IRFs to negative TFP shocks only. ${ }^{11}$ IRFs of Mauritania and Swaziland are not reported because they do not display rare events. Clearly, negative technology shocks have a negative impact on the income per worker growth rate, regardless of G7 or sub-Saharan economies. But, the impact is much higher in unlucky economies rather than in lucky ones (see vertical axes of Figs. A.4-A.7). In the unlucky world, the collapse of the per worker income in response to a negative shock ranges from $-2 \%$ to $-8 \%$, contrasted with $-0.1 \%$ to $-3 \%$ in the lucky world. We notice also that for some economies the impact is not statistically significant, such as in Cote d'Ivoire, Liberia, Sudan and Zambia. Where significant, it lasts on average for 1.5 years. For lucky economies, statistical results are less robust. We argue that the high order of magnitude of the impact in sub-Saharan economies is mostly driven by the presence of a higher TFP average volatility. Not surprisingly, the average TFP volatility across unlucky countries is roughly eight times higher than the average volatility computed across lucky economies (i.e. $0.729 \%$ vs $0.098 \%$ ). This is clear from Figs. A.1-A.3 which plot the TFP growth rate computed as in Eq. (2.5) - for the lucky and unlucky economies.

\footnotetext{
${ }^{11}$ Impulse responses to positive TFP shocks are available upon request.
} 
Table 4.1

Poverty headcount ratio at $\$ 2$ a day (PPP) (\% of population). Population below $\$ 2$ a day is the percentage of the population living on less than $\$ 2.00$ a day at 2005 international prices. Source: WORLD BANK.

\begin{tabular}{|c|c|c|c|c|c|c|c|c|c|c|}
\hline Country Name & 1981 & 1984 & 1987 & 1990 & 1993 & 1996 & 1999 & 2002 & 2005 & 2008 \\
\hline East Asia \& Pacific & 92.4 & 88.3 & 81.6 & 81 & 75.8 & 64 & 61.7 & 51.9 & 39 & 33.2 \\
\hline Europe \& Central Asia & 8.32 & 6.68 & 6.33 & 6.87 & 9.18 & 11.2 & 12.1 & 7.92 & 4.6 & 2.2 \\
\hline Latin America \& Caribbean & 23.8 & 26.8 & 22.4 & 22.4 & 21.7 & 21 & 22 & 22.2 & 16.7 & 12.4 \\
\hline Middle East \& North Africa & 30.1 & 27.1 & 26.1 & 23.5 & 22.1 & 22.2 & 22 & 19.7 & 17.4 & 13.9 \\
\hline South Asia & 87.2 & 85.6 & 84.5 & 83.6 & 82.7 & 80.7 & 77.8 & 77.4 & 73.4 & 70.9 \\
\hline Sub-Saharan Africa & 72.2 & 74.7 & 74.3 & 76 & 78.1 & 77.5 & 77.4 & 76.1 & 74.1 & 69.2 \\
\hline
\end{tabular}

\section{High standards of living in sub-Saharan Africa: A utopia}

"Africa is stuck in a poverty trap, too poor to achieve robust, high levels of economic growth and, in many places, simply too poor to grow at all"

Sachs et al. (2004)

Several basic elements related to sub-Saharan Africa's protracted puzzle of slow growth and underdevelopment are now fairly well recognized, even as the pathways to sustained growth remain only hazily understood. Sub-Saharan countries were long characterized by homogenous and stagnant economic growth rates, only recently showing more robust progress during the past decade. Recent growth notwithstanding, while the rest of the world has seen overall higher standards of living during the past three decades, Sub-Saharan economies as a whole got poorer (Table 4.1) (Bayraktara and Fofackb, 2011; The World Bank, 2010). Moreover, recent positive growth in sub-Saharan African countries is also associated with widening inequality between wealthier and poorer segments of the population (Ndulu et al., 2007), prompting attention to pro-poor growth strategies as well (Thorbecke, 2013).

While the complex interplay of drivers of sustained growth on this continent remain an enduring conundrum, much of the recent work around this issue increasingly emphasizes a wider lens beyond the traditional economic factors and various forms of capital. This shift includes a focus towards the mediating roles of an enabling institutional environment to support human resource capacity and facilitate technology innovations (Nelson, 2008), improved governance to support trade and market stability (Levchenko, 2007; Naude and Krugell, 2007; Meyer et al, 2009), and infrastructure investments to smooth geographic and endowment-linked barriers to economic diversification and trade (Ndulu, 2006).

Sachs et al. (2004) find that the per capita income growth rate in Africa during 1980-2000 is negative, and argue that African countries have the worst health condition of the planet as well as lowest government stability. Existing empirical findings also find that most developing countries that were poor in the 1950's remain so today, and most of these countries belong to the Sub-Saharan region. Although the existence of poverty traps continues to hold strong conceptual appeal for sub-Saharan Africa, the empirical evidence demonstrating mechanisms by which countries might move into or remain in such traps has been less forthcoming (Kraay and Raddatz, 2007). Conceptually, evidence for the existence of poverty traps can be indicated by a bimodal distribution of per capita income, such as we arguably observe in this analysis (i.e. poorer countries clustered around the lower poverty trap equilibrium and a richer countries clustered around the higher equilibrium). ${ }^{12}$ However, while a bi-modal distribution suggestive of traps is not uncommonly observed across much existing work, attempts to understand the causal mechanisms, which might lead to such a distribution, have yielded very little consensus. For instance, using data from microenterprises in Mexico, McKenzie and Woodruff (2008) suggest that the presence of large fixed costs to run a new business might be the main cause of an economies' poverty trap. At a more microlevel, Jalan and Ravallion (2002) argue that the availability of geographical capital (e.g. availability of roads, literacy levels) is key for sustaining growth. Kraay and Raddatz (2007) focus on both savings and productivity as causal mechanisms which could serve to generate poverty traps, but find little empirical support for either mechanism to operate in ways that could produce the particular equilibrium dynamics which underpin such conceptual models. Although an explicit test for empirical support of a dynamic poverty trap model is beyond the scope of our work here, our empirical results seem to add support for the existence of low-growth traps, and suggest that a low (or negative) average capital per worker accumulation as well as a negative TFP growth rate across unlucky economies could represent a mechanism by which countries remain in such traps. ${ }^{13}$

\section{Conclusion}

The roles of education and TFP in helping to explain cross-country income differences have been widely discussed and documented in the economic growth literature, ${ }^{14}$ even as very high income inequalities continue to persist between

\footnotetext{
${ }^{12}$ See Azariadis and Stachurski (2004a, b) and Quah (1993, 1996, 1997), among others.

${ }^{13}$ For a detailed discussion on the dynamics of the capital accumulation process in poor countries, see Bayraktara and Fofackb (2011), and Sachs et al. (2004).

14 See Caselli (2005), Hall and Jones (1999), and Sachs (2001), among many others.
} 
advanced and poor economies. In this relatively simple analysis, we confirm that the TFP (i.e. Solow's residual) seems to explain a larger portion of the income gap between Sub-Saharan and G7 economies than education (i.e. average years of schooling). On average the TFP in the unlucky world accounts only for $27 \%$ of the US TFP. Capital and education account for $39.4 \%$ and $60 \%$ respectively. Thus, it appears that income inequalities are driven more by differences in technological progress and physical capital, while education differences account only residually. We show that negative TFP uncertainty shocks, once they occur, further depress income per worker in the sub-Saharan zone, conceivably generating a feedback mechanism by which poorer countries continue to grow slowly. The magnitude of the impulse generated by the shock is on average much higher in the unlucky world than in the lucky one. We argue that the TFP volatility level affects the order of magnitude of the impact. In other words, the effect of large changes in the TFP level on a relatively low income per worker growth rate is higher than in an economy with a high income per worker growth rate. To conclude, we suggest that large differences in capital per worker and very low levels in the productivity of human capital across these two world regions adds conceptual support for the existence of poverty traps for Sub-Saharan Africa. Further work to understand how technology accumulation differences and shocks might mechanistically contribute to trap dynamics could help to elucidate appropriate policy responses for more sustained economic growth.

\section{Appendix A. On the TFP}

See Appendix Figs. A.1-A.7 and Table A.1
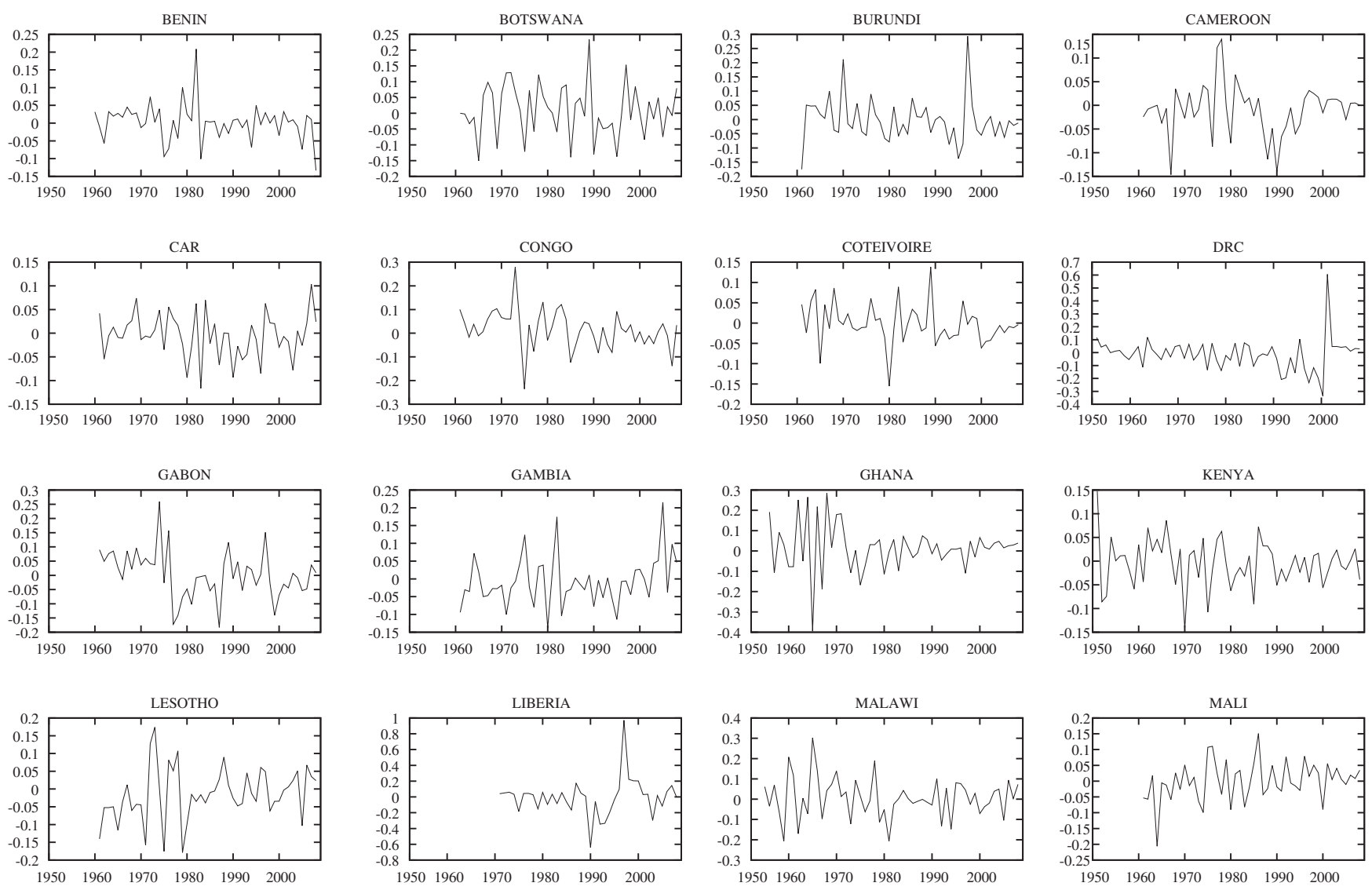

Fig. A.1. The Dynamics of the TFP Growth Rate (a). The TFP is computed as defined in Eq. (2.5). Data run from 1950 (or later) to 2009. 

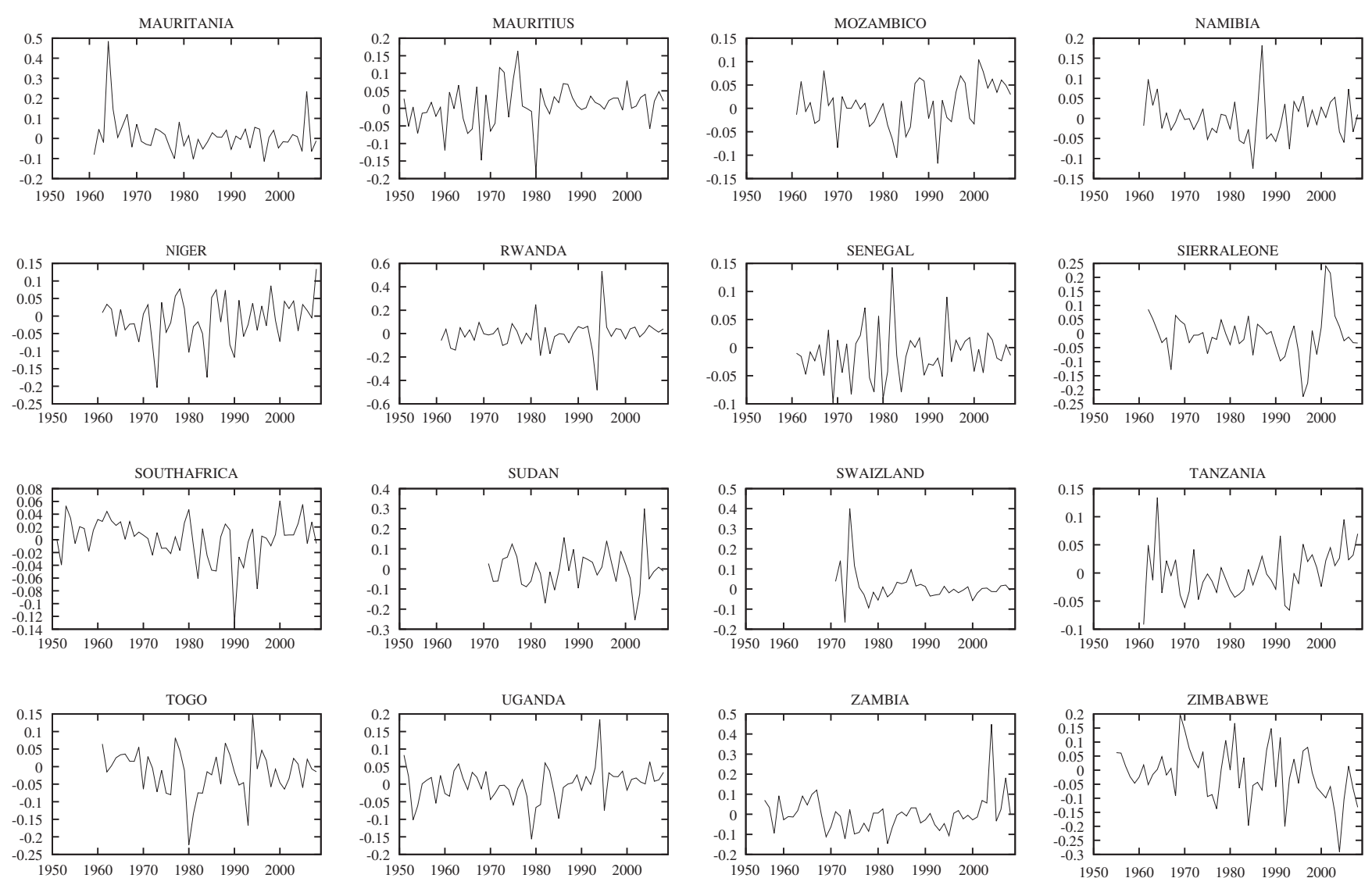

Fig. A.2. The Dynamics of the TFP Growth Rate (b). TFP is computed as defined in Eq. (2.5). Data run from 1950 (or later) to 2009.
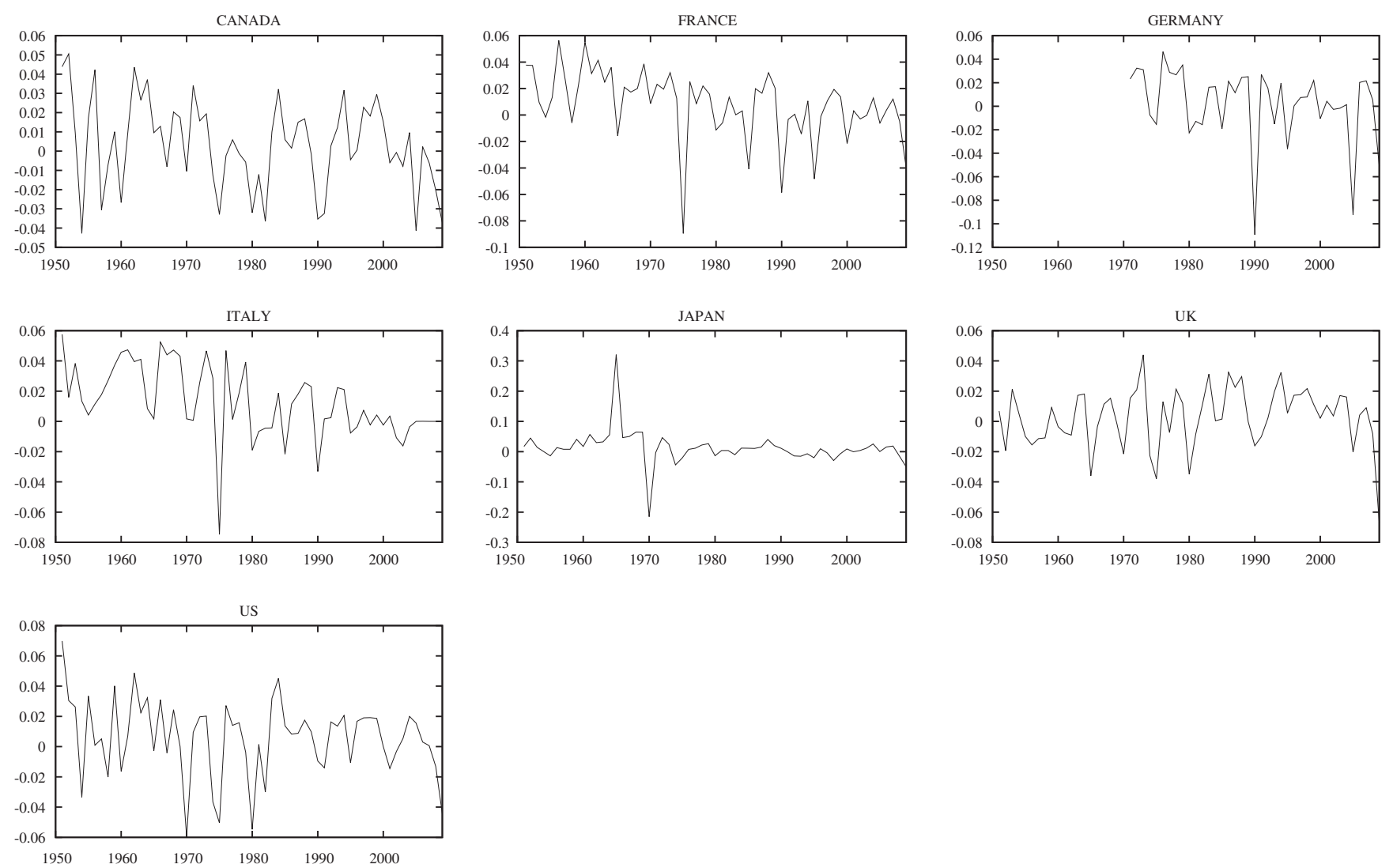

Fig. A.3. The Dynamics of the TFP Growth Rate (c). TFP is computed as defined in Eq. (2.5). Data run from 1950 (or later) to 2009. 

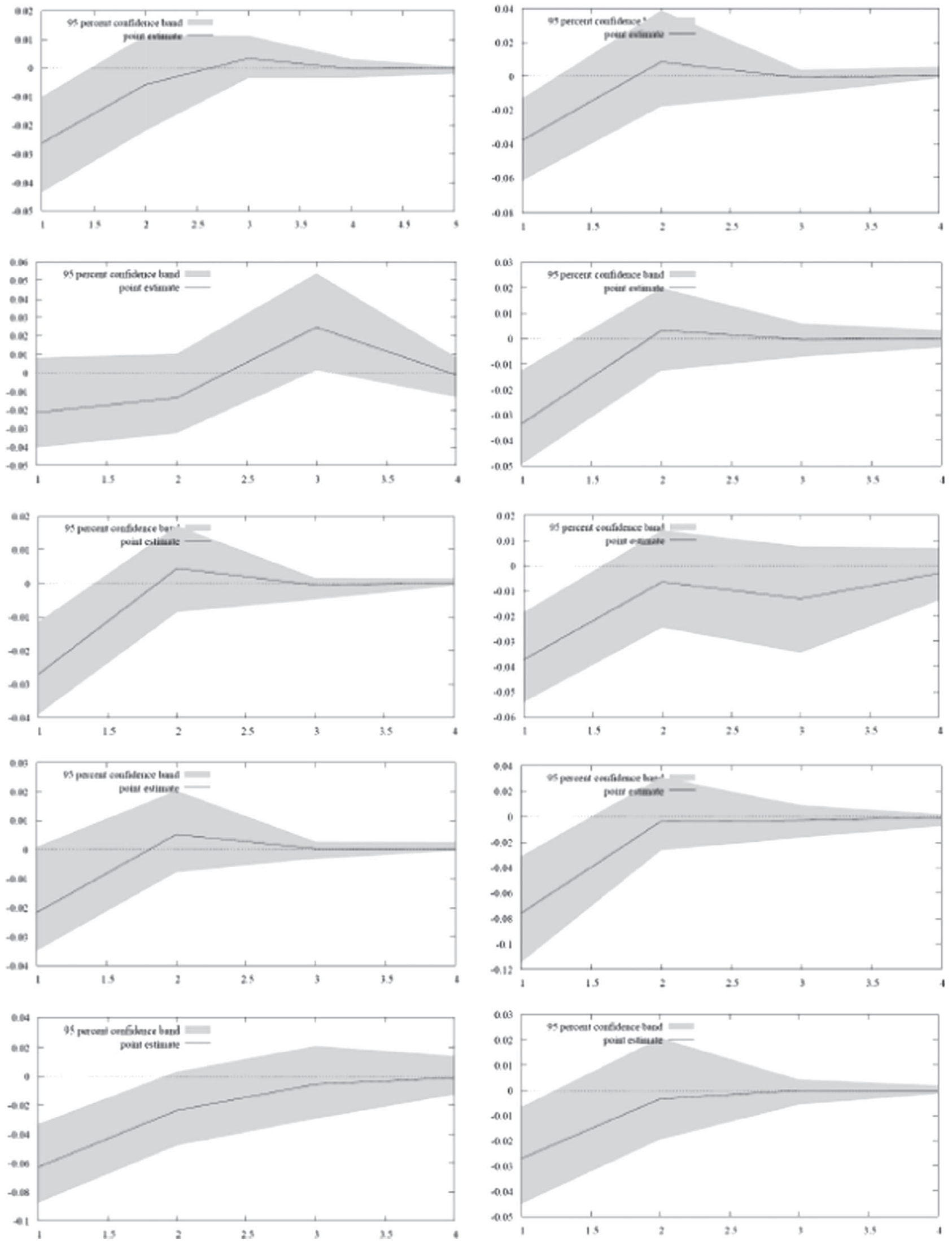

Fig. A.4. Sub-Saharan Economies IRFs: VAR estimation of the impact of $1 / 0$ negative TFP shock indicator on income per worker growth rate. The variable $y$ is from PWT63 PENN TABLE, and represents the real GDP per worker in international dollars (i.e. in PPP, this variable is called rgdpwok in the original data set). Standard errors are Newey and West $(1987,1994)$. Notes: shaded area represents $95 \%$ confidence bands around the response to $1 / 0$ negative TFP shock indicator. From top left: Benin, Botswana, Burundi, Cameroon, Central African Republic, Congo, Cote d' Ivoire, Dem. Rep. Congo, Gabon and Gambia. Data run from 1950 (or later) to 2009. 

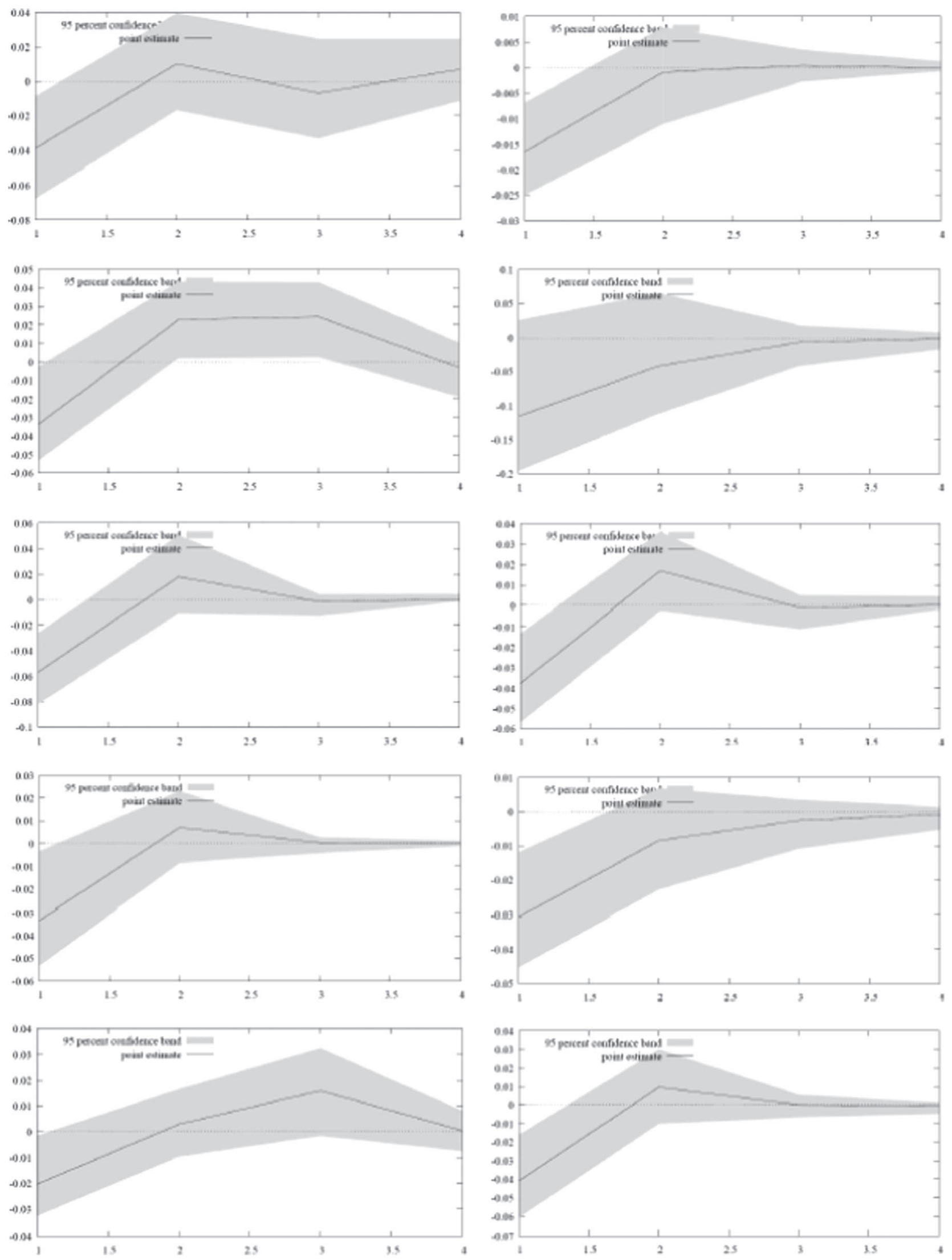

Fig. A.5. Sub-Saharan Economies IRFs: VAR estimation of the impact of $1 / 0$ negative TFP shock indicator on income per worker growth rate. The variable $y$ is from PWT63 PENN TABLE, and represents the real GDP per worker in international dollars (i.e. in PPP, this variable is called rgdpwok in the original data set). Standard errors are Newey and West $(1987,1994)$. Notes: shaded area represents $95 \%$ confidence bands around the response to $1 / 0$ negative TFP shock indicator. From top left: Ghana, Kenya, Lesotho, Liberia, Malawi, Mali, Mauritius, Mozambique, Namibia and Niger. Data run from 1950 (or later) to 2009. 

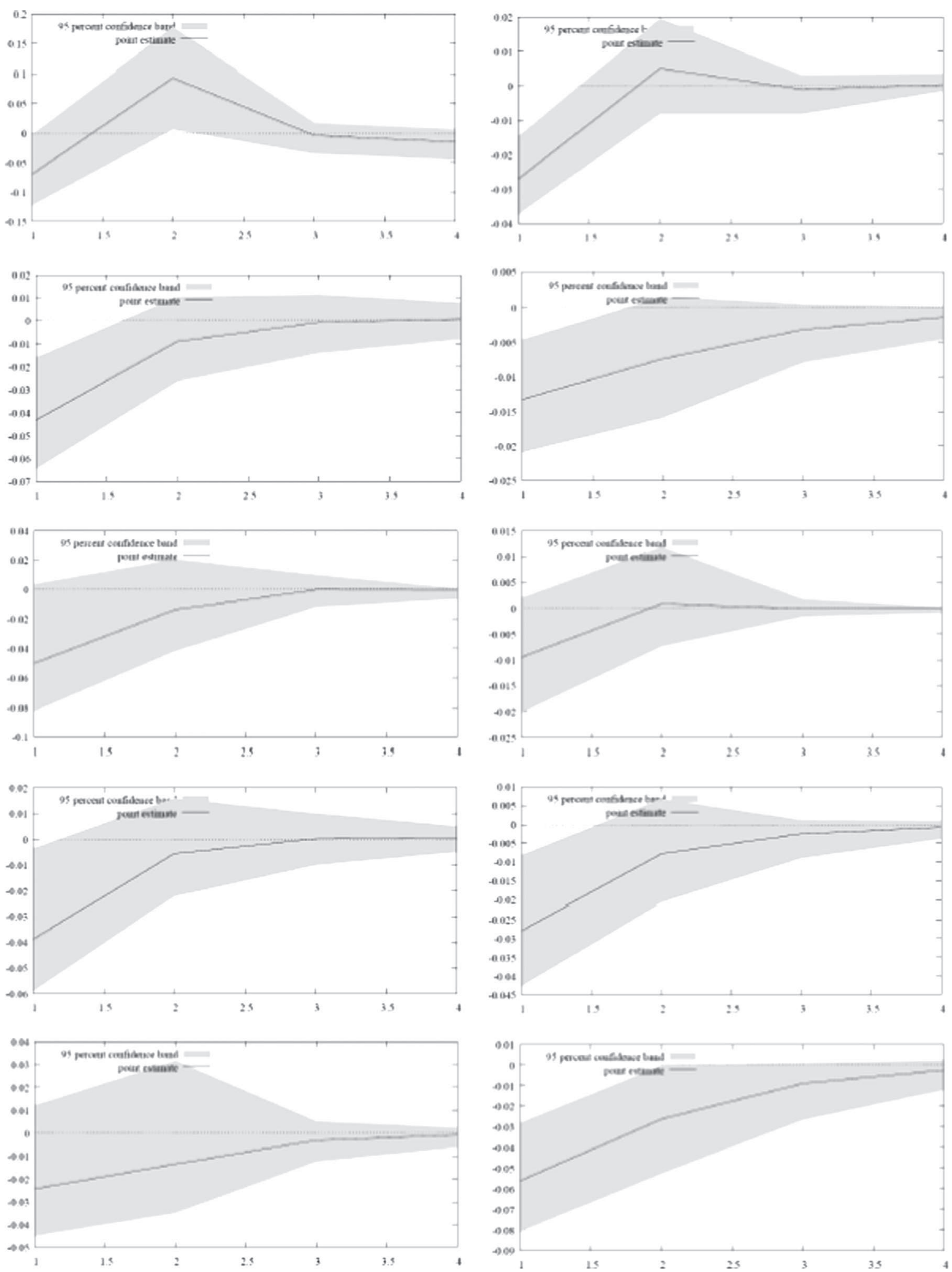

Fig. A.6. Sub-Saharan Economies IRFs: VAR estimation of the impact of $1 / 0$ negative TFP shock indicator on income per worker growth rate. The variable $y$ is from PWT63 PENN TABLE, and represents the real GDP per worker in international dollars (i.e. in PPP, this variable is called rgdpwok in the original data set). Standard errors are Newey and West $(1987,1994)$. Notes: shaded area represents $95 \%$ confidence bands around the response to $1 / 0$ negative TFP shock indicator. From top left: Rwanda, Senegal, Sierra Leone, South Africa, Sudan, Tanzania, Togo, Uganda, Zambia, Zimbabwe. Data run from 1950 (or later) to 2009. 

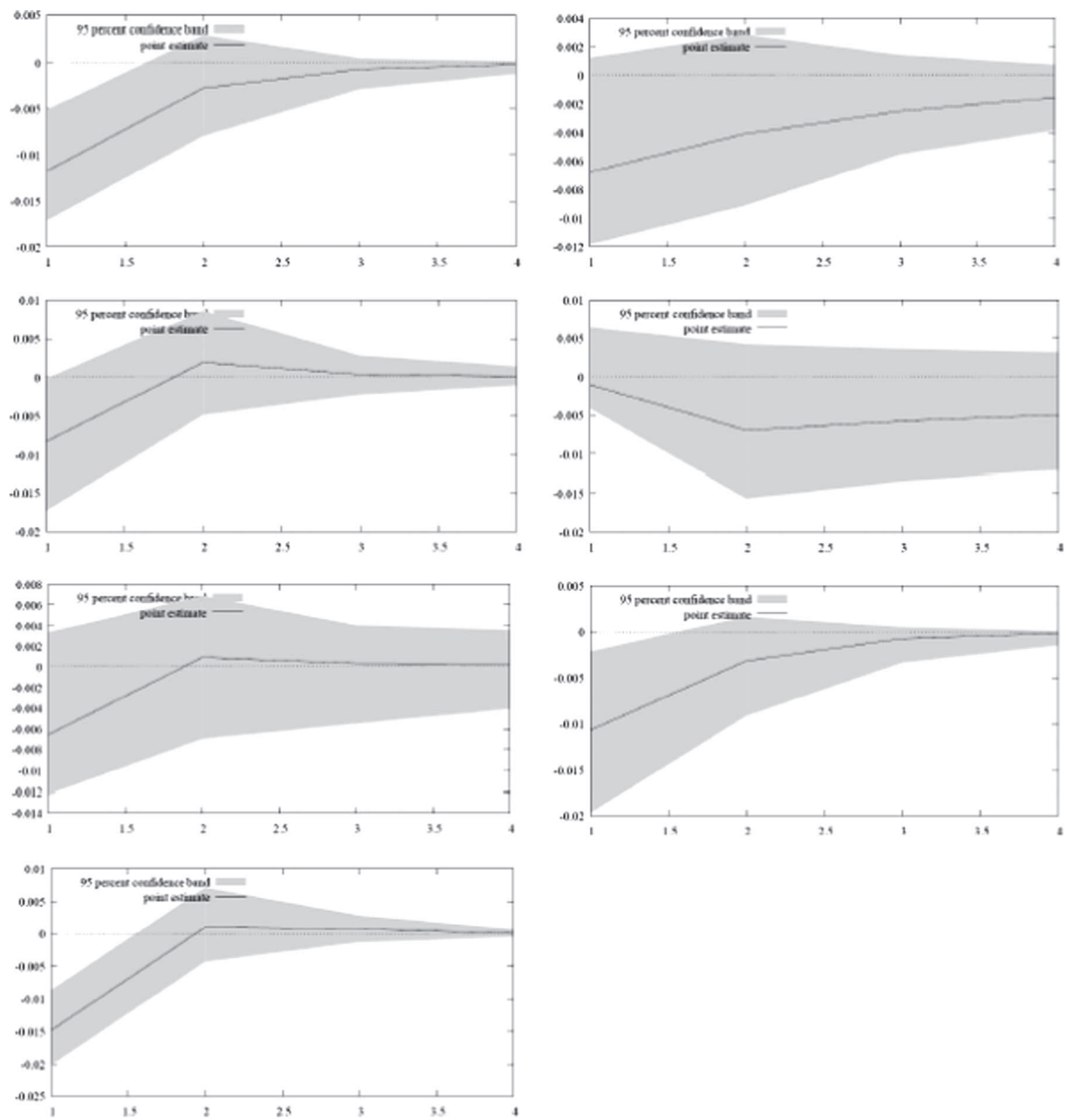

Fig. A.7. G7 Economies IRFs: VAR estimation of the impact of $1 / 0$ negative TFP shock indicator on income per worker growth rate. The variable $y$ is from PWT63 PENN TABLE, and represents the real GDP per worker in international dollars (i.e. in PPP, this variable is called rgdpwok in the original data set). Standard errors are Newey and West $(1987,1994)$. Notes: shaded area represents $95 \%$ confidence bands around the response to $1 / 0$ negative TFP shock indicator. From top left: Canada, France, Germany, Italy, Japan, United Kingdom and USA. Data run from 1950 (or later) to 2009. 


\section{Table A.1}

TFP uncertainty shocks: positive or negative signs (in parentheses) confirm the presence of extreme movements in the TFP growth rate series. A (+) is assigned when TFP Growth Rate $>\mu_{A}^{h p}+1.43 \sigma_{A}$ and a (-) is assigned when TFP Growth Rate $>\mu_{A}^{h p}-1.43 \sigma_{A}$. The variable $\mu_{A}^{h p}$ represents the sample mean of the TFP growth rate Hodrick and Prescott (1997) filtered series. Dates.

Sources: PENN WORLD Tables, Barro-Lee Dataset.

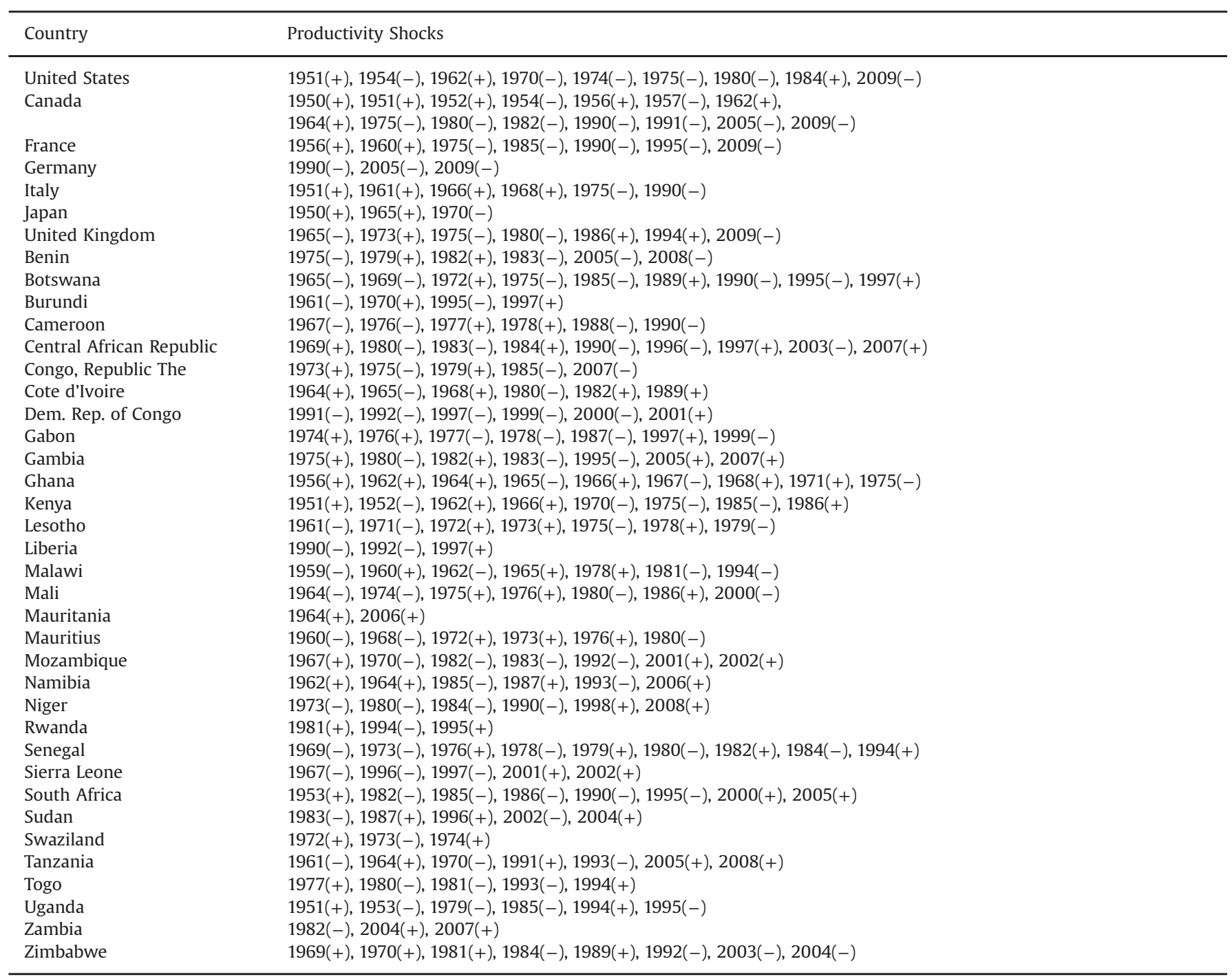

\section{References}

Acemoglu, D., Simon, J., Robinson, J., Thaicharoen, Y., 2003. Institutional causes, macroeconomic symptoms: volatility, crises and growth. Journal of Monetary Economics 50 (1), 49-123.

Azariadis, C. Stachurski, J., 2004a. Poverty Traps. In: Aghion, Durlauf (Eds.), Handbook of Economic Growth.

Azariadis, C. Stachurski, J., 2004b. A Forward Projection of the Cross-country Income Distribution. Manuscript, UCLA.

Bayraktara, N., Fofackb, H., 2011. Capital accumulation in sub-Saharan Africa: income-group and sector differences. Journal of African Economies 20 (4), $531-561$.

Bloom, N., 2009. The impact of uncertainty shocks. Econometrica 77 (3), 623-685.

Caselli, F., 2005. Accounting for cross-country income differences. first ed. In: Aghion, Philippe, Durlauf, Steven (Eds.), Handbook of Economic Growth, vol. 1., Elsevier, pp. 679-741. chapter 9.

Cazzavillan, G. Donadelli, M., 2013. The 2007-2009 Global Demand Collapse: Rare Events and Policy Effectiveness. Unpublished manuscript (〈http://papers. ssrn.com/sol3/papers.cfm?abstract_id=1893382〉).

Clinton, 2000. Address to a Joint Session of the Indian Parliament, March 2000.

Ehrlich, I. Lui, F.T., 1999. Bureaucratic Corruption and Endogenous Economic Growth. The Journal of Political Economy, 107(6), Part 2: Symposium on the Economic Analysis of Social Behavior in Honor of Becker, G.S., S270-S293.

Hall, R.E., Jones, C.I., 1999. Why do some countries produces so much more output per worker than others? The Quarterly Journal of Economics 114 (1), $83-116$.

Hodrick, R., Prescott, E.P., 1997. Post-war business cycles: an empirical investigation. Journal of Money, Credit, and Banking $29,1-16$.

Jalan, J., Ravallion, M., 2002. Geographic poverty traps? A micro model of consumption growth in rural China. Journal of Applied Econometrics 17 (4), 329-346.

Kraay, A., Raddatz, C., 2007. Poverty traps, aid, and growth. Journal of Development Economics 82 (2), $315-347$. 
Kremer, M., Maskin, E., 2003. Globalization and inequality. Harvard Department of Economics and IAS, mimeo.

Levchenko, A.A., 2007. Institutional quality and international trade. Review of Economic Studies 74 (3), $791-819$.

Mauro, P., 1995. Corruption and growth. The Quarterly Journal of Economics 110 (3), 681-712.

Mazur, J., 2000. Labors New Internationalism. Foreign Affairs, Jan./Feb. 2000.

McKenzie, D., Woodruff, C., 2008. Experimental evidence on returns to capital and access to finance in Mexico. World Bank Economic Review 22 (3), 457-482.

Meyer, K.E., Estrin, S., Bhaumik, S.K., Peng., M.W., 2009. Institutions, resources and entry strategies in emerging economies. Strategic Management Journal $30(1), 61-80$

Naude, W.A., Krugell, W.F., 2007. Investigating geography and institutions as determinants of foreign direct investment in Africa using panel data. Applied Economics 39, 1223-1233.

Ndulu, B.J., 2006. Infrastructure, regional integration and growth in Sub-Saharan Africa: dealing with the disadvantages of geography and sovereign fragmentation. Journal of African Economies 15 (2), 212-244.

Ndulu, B., Chakraborti, L., Lijane, L., Ramachandran, V., Wolgin, J., 2007. Challenges of African Growth: Opportunities, Constraints and Strategic Directions. The World Bank, Washington, DC.

Nelson, R.R., 2008. What enables rapid economic progress: what are the needed institutions? Research Policy 37 (1), 1-11.

Newey, W.K., West, K.D., 1987. A simple, positive semi-definite, heteroskedasticity and autocorrelation consistent covariance matrix. Econometrica 55 (3), $703-708$

Newey, W.K., West, K.D., 1994. Automatic lag selection in covariance matrix estimation. Review of Economic Studies 61 (4), $631-654$.

North, D.C., 1990. Institutions, Institutional Change and Economic Performance. Cambridge University Press, Cambridge.

North, D.C., 1994. Economic Performance Through Time. American Economic Review 84 (3), 359-368.

Parente, S.L., Prescott, E.C., 1994. Barriers to technology adoption and develop ment. Journal of Political Economy 102 (2), $298-321$.

Pritchett, L., 1996. Where has all the Education Gone?. World Bank Policy Research Working Paper n. 1581.

Quah, D.T., 1993. Empirical cross-section dynamics in economic growth. European Economic Review 37, 426434.

Quah, D.T., 1996. Twin peaks: growth and convergence in models of distribution dynamics. Economic Journal 106 (127), $1045-1055$.

Quah, D.T., 1997. Empirics for growth and distribution: stratification, polarization, and convergence clubs. Journal of Economic Growth 2, 2759.

Sachs, J.D., 2001. Tropical Underdevelopment. NBER Working Paper n. 8119.

Sachs, J.D., McArthur, J.W., Schmidt-Traub, G., Kruk, M., Bahadur, C., Faye, M., McCord, G., 2004. Ending Africa’s poverty trap. Brookings Papers on Economic Activity 35 (1), 117-240.

Shleifer, A., Vishny, R.W., 1993. Corruption. The Quarterly Journal of Economics 108 (3), 599-617.

The World Bank. 2010. World Development Indicators, 2010. Washington, DC.

Thorbecke, E., 2013. The interrelationship linking growth, inequality and poverty in Sub-Saharan Africa. Journal of African Economies 22 (1), 15-48. 